\title{
PENERAPAN DINAMIKA KELOMPOK SOSIAL DALAM MENINGKATKAN PERKEMBANGAN ANAK USIA TODDLER DI POSYANDU KELURAHAN LIRBOYO KEDIRI
}

\author{
Erna Susilowati*1, Elfi Quyumi R*2 \\ * ${ }^{1,2}$ Akademi Keperawatan Dharma Husada Kediri \\ E-mail :ernabudi_80@yahoo.co.id.
}

\section{ABSTRACT}

A healthy child will show optimal growth if given an adequate bio-physic and psychosocial environment. Each parent wishes that her child can grow optimally with growth that achieves the best growth and development according to the genetic potential that is present in the child and this must be fulfilled from an early age. The purpose of this study is to determine the effect of social group dynamics in improving the development of toddler age children. This research is a pre experimental research with one group pre-post test design approach on toddler age population in Lirboyo Kediri village. Subjects were taken by random sampling of 50 children. Child development data was obtained by DDST (Denver Devalopment Screning Test) measurement. Data analysis using bivariate analysis is Wilcoxon different test with significance level $\alpha=0.05$. The result of this research is the influence of social group dynamics with personal social development ( $p 0,000)$. There is influence of social group dynamics with fine motor development (p 0.003), There is influence of social group dynamics on language development (p 0,000) gross motor development ( $p$ 0.003) with early detection of growth of Todler-age children is expected to delay the development of children can be prevented.

Keywords: Social Group Dynamics, development, toddler child

\section{PENDAHULUAN}

Penilaian tumbuh kembang perlu dilakukan untuk menentukan apakah tumbuh kembang anak berjalan normal atau tidak baik dilihat dari segi medis maupun statistic. Anak sehat akan menunjukkan tumbuh kembang yang optimal apabila diberikan lingkungan biofisiko dan psikososial yang adekuat. Setiap orang tua berkeinginan agar anaknya dapat tumbuh kembang dengan optimal yang mencapai pertumbuhan dan perkembangan yang terbaik sesuai dengan potensi genetic yang ada pada anak dan hal ini harus dipenuhi sejak dini. Dinamika kelompok social adalah kegiatan pendidikan yang dilakukan dengan cara menyebarkan pesan sehingga masyarakat tidak saja sadar, tau dan mengerti tetapi juga mau dan bisa melakukan suatu anjuran yang ada hubungan dengan kesehatan. Dinamika kelompok social adalah gabungan berbagai kegiatan dan kesempatan yang berlandaskan prinsip - prinsip belajar untuk mencapai sesuatu keadaan dimana individu, keluarga dan kelompok atau masyarakat melakukan apa yang bisa dilakukan secara perseorangan maupun secara kelompok dan memina pertolongan.

Lingkungan pengasuhan juga berdampak dalam memberikan stimulasi pada anak. Lingkungan pengasuhan juga di pengaruhi jumlah ana., Jumlah saudara yang banyak pada keluarga yang keadaan social ekonominya cukup akan mengakibatkan berkurangnya perhatian dan kasih saying yang diterima anak. Perkembangan anak penting dijadikan perhatian khusus bagi orang tua sebab proses tumbuh kembang akan mempengaruhi kehidupan mereka pada masa mendatang. Jika perkembangan anak luput dari perhatian orang tua (tanpa arahan dan pendampingan orang tua) 
maka anak akan tumbuh seadanya sesuai dengan yang hadir dan menghampiri mereka.

Dampak kurang gizi terhadap perkembangan mental dan otak tergantung dengan derajat beratnya, lamanya dan waktu pertumbuhan otak itu sendiri. Jika kondisi kurang Gizi terjadi pada Todler, khususnya pada golden periode perkembangan otak, otak tidak dapat berkembang sebagaimana anak yang sehat, dan kondisi ini akan sulit untuk dapat pulih kembali. Dengan demikian dikhawatirkan anak yang menderita gizi kurang pada usia toddler akan mengalami gangguan perkembangan yang bersifat menetap di masa - masa berikutnya. Perkembangan memiliki tahapan yang berurutan mulai dari melakukan hal yang sederhana menuju kemampuan melakukan hal yang sempurna dan setiap individu memiliki kecepatan perkembangan yang berbeda.

Aspek perkembangan yang dipantau adalah motorik kasar, motorik halus, kemampuan bahasa dan bicara serta sosialisasi dan kemandirian. Salah satu upaya untuk mengetahui adanya penyimpangan perkembangan anak toddler yaitu dengan detekdi dini penyimpangan perkembangan anak. Melalui deteksi dini ini maka pemulihan dapat dilakukan lebih awal sehingga tumbuh kembang dapat berlangsung optimal.

\section{METODE PENELITIAN}

Penelitian ini menggunakan desain penelitian pra eksperimen dengan pendekatan one group pra-post test design Populasi dalam penelitian ini adalah seluruh anak usia toddler yang berkunjung ke Posyandu Melati dan Menur Kelurahan Lirboyo Mojoroto Kediri pada bulan Juni 2017 yang berjumlah 50 anak.Instrumen yang digunakan adalah lembar observasi Denver II untuk mengukur perkembangan anak.

Pengolahan data yang diperopleh dari hasil penelitian ini diolah secara manual dengan menentukan perkembangan anak selanjutnya dilakukan analisis menggunakan program pengolahan statistic. Setelah itu diolah menggunakan system computer, tahapan tersebut yaitu editing, coding dan entering. Analisa data dalam penelitian ini yaitu analisa bivariat yaitu analisa yang dilakukan terhadap dua variable yang diduga atau berkorelasi. Dilakukan uji statistic Wicoxon dengan derajat kemaknaan $95 \%(\alpha 0,05)$.

\section{HASIL PENELITIAN}

Pengaruh Dinamika Kelompok Sosial dalam Meningkatkan Kemampuan Personal Sosial Anak Toddler

Tabel 1 Pengaruh Dinamika Kelompok Sosial dalam Meningkatkan Kemampuan Personal Sosial Anak Toddler di Kelurahan Lirboyo

\begin{tabular}{lcccc} 
Personal & $\begin{array}{c}\text { Sebelum } \\
\text { dinamika } \\
\text { sesial }\end{array}$ & $\begin{array}{c}\text { kelompok } \\
\text { sosial }\end{array}$ & \multicolumn{2}{c}{$\begin{array}{c}\text { Sesudah } \\
\text { dinamika } \\
\text { kelompok } \\
\text { sosial }\end{array}$} \\
\cline { 2 - 5 } Lebih & $\mathrm{n}$ & $\mathrm{c}$ & $\mathrm{n}$ & $\mathrm{c} /$ \\
Normal & 0 & 0 & 5 & 10 \\
Caution & 34 & 68 & 45 & 90 \\
Delay & 11 & 22 & 0 & 0 \\
Total & 5 & 10 & 0 & 0 \\
$\mathrm{p}$ & 50 & 100 & 50 & 100 \\
\hline
\end{tabular}

1. Pengaruh Dinamika Kelompok Sosial dalam Meningkatkan Perkembangan Motorik Halus pada Anak Toddler

Tabel 2 Pengaruh Dinamika Kelompok Sosial dalam Meningkatkan Perkembangan Motorik Halus pada Anak Toddler di Kelurahan Lirboyo Kediri

\begin{tabular}{ccccc}
\hline \multirow{2}{*}{$\begin{array}{c}\text { Motorik } \\
\text { halus }\end{array}$} & $\begin{array}{c}\text { Sebelum } \\
\text { dinamika } \\
\text { kelompok } \\
\text { sosial }\end{array}$ & \multicolumn{2}{c}{$\begin{array}{c}\text { Sesudah } \\
\text { dinamika } \\
\text { kelompok } \\
\text { sosial }\end{array}$} \\
\cline { 2 - 5 } Lebih & $\mathrm{n}$ & $\mathrm{c}$ & $\mathrm{n}$ & $\mathrm{c}$ \\
Normal & 38 & 0 & 0 & 0 \\
Caution & 2 & 76 & 46 & 92 \\
Delay & 10 & 20 & 0 & 8 \\
Total & 50 & 100 & 50 & 100 \\
$\mathrm{p}$ & 0,003 & & & \\
\hline
\end{tabular}


2. Pengaruh Dinamika Kelompok Sosial dalam Meningkatkan Perkembangan Bahasa Anak Toddler

Tabel 3 Pengaruh Dinamika Kelompok Sosial dalam Meningkatkan Perkembangan Bahasa Anak Toddler di kelurahan Lirboyo Kediri

\begin{tabular}{ccccc}
\hline Bahasa & \multicolumn{2}{c}{$\begin{array}{c}\text { Sebelum } \\
\text { dinamika } \\
\text { kelompok sosial }\end{array}$} & \multicolumn{2}{c}{$\begin{array}{c}\text { Sesudah } \\
\text { dinamika } \\
\text { kelompok sosial }\end{array}$} \\
\cline { 2 - 5 } Lebih & 0 & 0 & 0 & 0 \\
Normal & 24 & 48 & 37 & 74 \\
Caution & 4 & 8 & 13 & 26 \\
Delay & 22 & 44 & 0 & 0 \\
Total & 50 & 100 & 50 & 100 \\
p & 0,003 & & & \\
\hline
\end{tabular}

3. Pengaruh Dinamika Kelompok Sosial dalam Meningkatkan Perkembangan Motorik Kasar pada anak Toddler

Tabel 4 Pengaruh Dinamika Kelompok Sosial dalam Meningkatkan Perkembangan Motorik Kasar pada anak Toddler di kelurahan Lirboyo Kediri

\begin{tabular}{ccccc}
\hline \multirow{2}{*}{$\begin{array}{c}\text { Motorik } \\
\text { kasar }\end{array}$} & $\begin{array}{c}\text { Sebelum } \\
\text { dinamika } \\
\text { kelompok } \\
\text { sosial }\end{array}$ & \multicolumn{2}{c}{$\begin{array}{c}\text { Sesudah } \\
\text { dinamika } \\
\text { kelompok } \\
\text { sosial }\end{array}$} \\
\cline { 2 - 5 } Lebih & $\mathrm{n}$ & $\mathrm{c}$ & $\mathrm{n}$ & $\mathrm{c}$ \\
Normal & 38 & 0 & 0 & 0 \\
Caution & 2 & 4 & 13 & 26 \\
Delay & 10 & 20 & 0 & 8 \\
Total & 50 & 100 & 50 & 0 \\
$\mathrm{p}$ & 0,003 & & & \\
\hline
\end{tabular}

\section{PEMBAHASAN}

1. Pengaruh Dinamika Kelompok Sosial dalam Meningkatkan Kemampuan Personal Sosial Anak Toddler

Berdasarkan tabel 1 didapatkan adanya pengaruh yang signifikan antara pelaksanaan dinamika kelompok sosial dengan perkembangan anak usia toddler. Sebelum pelaksanaan dinamika kelompok sosial ada anak yang mengalami Delay sebanyak $10 \%$. Terdapat banyak masalah dalam perkembangan personal sosial anak toddler seperti anak belum mampu menggunakan sendok atau garpu sebagai alat makannya. Anak belum mampu minum dengan cangkir karena orang tuanya membiasakan minum dengan dot. Anak cenderung takut untuk bersosialisasi. Personal social anak usia toddler dapat dipengaruhi oleh pemenuhan gizi yang seimbang. Anak dengan perkembangangan sosial yang baik maka dia akan mampu melaksanakan penyesuaian diri terhadap lingkungan sosialnya dengan baik, mandiri dan tidak selalu bergantung dengan orang tuanya. Anak mudah diterima dalam anggota kelompok sosialnyadan dapat mengontrol diri dengan baik. Anak mampu mempunyai hubungan baik dengan temannya dan kooperatif terhadap orang lain. Sebagian besar anak toddler di kelurahan Lirboyo menunjukkan ekspresi cemas dan menangis saat dilakukan penimbangan berat badan oleh kader Posyandu. Anak terlihat tidak kooperatif.

Anak yang mempunyai perkembangan personal sosial yang baik akan dapat berhubungan sosial dengan baik di masyarakat dan anak juga bisa belajar memenuhi kebtuhanya sendiri. Anak usia toddler yang tidak terpenuhi perkembangan personal sosialnya akan mengalami masalah dalam perkembangan sosialnya. Anak dengan masalah perkembangan personal sosial akan memiliki prestasi belajar yang kurang, suka marah, suka berkelahi, suka menantang dan suka menangis. Kemampuan personal sosial meliputi aspek kemandirian, kemampuan dan bersosialisasi serta berinteraksi dengan lingkungan merupakan hal yang penting untuk dimiliki anak. Perkembangan personal sosial pada anak toddler dapat 
dipengaruhi oleh status gizi, stimulasi dan lingkungan yang kondusif.

2. Pengaruh Dinamika Kelompok Sosial dalam Meningkatkan Perkembangan Motorik Halus pada Anak Toddler

Berdasarkan tabel 3 didapatkan terdapat pengaruh yang signifikan antara pelaksanaan dinamika kelompok sosial dengan perkembangan motorik halus anak usia toddler dengan nilai $\mathrm{p}=0.003$. Perkembangan anak sangat erat kaitannya dengan pertumbuhan fisik. Anak yang sehat antara pertumbuhan fisik dan perkembangan motoriknya akan sejalan seiring pertambahan umur anak. Perkembangan motorik anak dipengaruhi oleh asupan gizinya (Tayong,2016)

Gerakan motorik halus tidak dapat dilakukan sempurna bila mekanisme otot belum berkembang, hal ini terjadi pada anak yang mengalami gangguan pertumbuhan dimana otot berbelang (striped muscle) atau striated muscle yang mengendalikan gerakan sukarela berkembang dalam laju yang agak lambat (Hurloc EB,1978). Tingkat kecukupan energi, protein dan seng memiliki hubungan yang bermakna dengan perkembangan motorik halus anak. Asupan gizi merupakan faktor yang sangat penting serta faktor langsung mempengaruhi tumbuh kembang anak. Saat ini gangguan pertumbuhan dan perkembangan masih menjadi salah satu permasalahan. Salah satu aspek yang dapat dipantau adalah perkembangan anak usia toddler adalah gerak halus atau motorik halus.

3. Pengaruh Dinamika Kelompok Sosial dalam Meningkatkan Perkembangan Bahasa Anak Toddler .

Berdasakan table 4 didapatkan hasil adanya pengaruh antara dinamika kelompok sosial dengan perkembangan bahasa anak usia toddler dengan nilai $\mathrm{p}$ $=0.003$. Dampak kurang gizi terhadap perkembangan mental dan otak tergantung dengan derajat beratnya, lamanya dan waktu pertumbuhan otak jika kondisi kurang gizi terjadi pada toddler, otak tidak dapat berkembang sesuai dengan usianya dan kondisi ini akan sulit untuk pulih kembali atau bersifat irreversible (Nency, 2005). Masa toddler merupakan masa golden periode untuk perkembangan otak. Kemampuan bicara dan bahasa adalah aspek yang berhubungan dengan kemampuan untuk memberikan respon terhadap suara, berbicara, berkomunikasi mengikuti perintah dan sebagainya.

Pemeroleh bahasa (Language Acquition menurut Maksan dalam Suhartono,2005) adalah suatu proses penguasaan bahasa yang dilakukan oleh sesorang secara tidak sadar, implicit dan informal. Anak memperoleh pengetahuan tentang bahasa dari lingkungannya baik lingkungan keluarga, masyarakat juga lingkungan pergaulan, teman sebaya yang berkembang didalam keluarga (Susanto,2011)

Secara fisik, kemampuan anak dalam memproduksi kata-kata ditandai oleh perkembangan bibir, lidah dan gigi mereka yang sedang tumbuh. Pada tahap tertentu pemerolehan bahasa (kemampuan mengucapkan dan memahami arti kata juga tidak lepas dari kemampuan mendengarkan, melihat dan mengartikan simbol-simbol bunyi dengan kematangan otaknya. Secara psikis kemampuan memproduksi kata-kata dan variasi ucapan sangat ditentukan oleh emosional anak saat berlatih mengucapkan kata. Anak yang mendapat bimbingan dan dorongan moral yang sangat kuat akan memperoleh kata-kata yang banyak dan bervariasi dibandingkan anak lainnya.

4. Pengaruh Dinamika Kelompok Sosial dalam Meningkatkan Perkembangan Motorik Kasar pada anak Toddler

Menurut Soetjiningsih (2014) faktor yang dapat mempengaruhi perkembangan 
anak adalah faktor genetik dan faktor lingkungan. Hal-hal yang termasuk pada faktor lingkungan diantaranya nutrisi dan stimulasi. Asupan nutrisi akan mempengaruhi status gizi anak yang berhubungan dengan tumbuh kembangnya. Perkembangan motorik kasar merupakan aspek perkembangan lokomosi (gerakan) dan postur (posisi tubuh). Stimulasi dan pemberian asupan nutrisi yang baik termasuk dalam kebutuhan dasar anak yang harus dipenuhi. Perkembangan motorik kasar di usia balita terkait erat dengan perkembangan fisik dan rasa percaya diri. Apabila pada usia tertentu belum bisa melakukan motorik kasar maka anak telah mengalami keterlambatan. Kemampuan motorik anak semakin baik dengan meningkatnya usia karena kematangan funsi tubuh dan ototnya

\section{KESIMPULAN}

1. Terdapat perbedaan antara perkembangan personal sosial anak usia Toddler sebelum dan sesudah intervensi Dinamika Kelompok Sosial pada orang tua yang mempunyai anak Toddler di Kelurahan Lirboyo Kediri $(\mathrm{p}=0.000)$

2. Terdapat perbedaan antara perkembangan Motorik Halus anak usia Toddler sebelum dan sesudah intervensi Dinamika Kelompok Sosial pada orang tua yang mempunyai anak Toddler di Kelurahan Lirboyo Kediri $(\mathrm{p}=0,003)$

3. Terdapat perbedaan antara perkembangan bahasa anak usia Toddler sebelum dan sesudah intervensi Dinamika Kelompok Sosial pada orang tua yang mempunyai anak Toddler di Kelurahan Lirboyo Kediri $(\mathrm{p}=0,000)$

4. Terdapat perbedaan antara perkembangan motorik kasar anak usia Toddler sebelum dan sesudah intervensi Dinamika Kelompok Sosial pada orang tua yang mempunyai anak
Toddler di Kelurahan Lirboyo Kediri $(\mathrm{p}=0,003)$

\section{SARAN}

Bagi orang tua dan keluarga yang memiliki anak toddler dengan status gizi kurang dapat meluangkan waktu lebih untuk mengawasi perkembangan anak dan memberikan menu gizi seimbang khususnya dalam masa pertumbuhan dan perkembangan. Orang tua dapat memberikan stimulasi untuk perkembangan anak. Orang tua selalu menerapkan dan mengajarkan pada anak tentang perilaku hidup bersih dan sehat.

\section{DAFTAR PUSTAKA}

Aisha KYousafzai, Muneera ARasheedMSc. Effect of integrated responsive stimulation and nutrition interventions in the Lady Health Worker programme in Pakistan on child development, growth, and health outcomes: a clusterrandomised factorial effectiveness trial. Child Neuropsychology Journal. Volume 384, Issue 9950, 410 October 2014, Pages 1282-1293

Amina Abubakar, FonsVan de Vijver, Anneloes Van Baar. Socioeconomic status, anthropometric status, and psychomotor development of Kenyan children from resource-limited settings: A path-analytic study. Early Human Development Jurnal. Volume

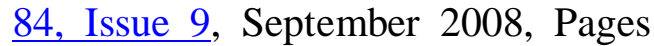
613-621

Christine Mariana Taju, Amatus Y, Abraham B. 2005. Hubungan status pekerjaan ibu dengan perkembangan motorik halus dan motorik kasar anak usia prasekolah di PAUD. E journal keperawatan (e-kp) volume 3 No 2 Mei 2015

Desmika Wantika S. 2012. Hubungan antara status gizi dengan 
perkembangan motorik kasar anak usia 1-5 tahun di Posyandu Buah Hati Ketelan Banjarsari Surakarta, Jurnal Kesehatan vol 5 No 2 Desember 2012 : 157-164

Fabrina Suci Hati, Prasetya Lestari. 2016. Pengaruh pemberian stimulasi pada perkembangan anakusia 12-36 bulan di Kecamatan Sedayu Bantul. Journal Ners and Midwifery Indonesia (JNKI) Vol 2 No 1 th 2016 44-48.

Francisco J. Rosales, J. Steven Reznick \& Steven H. Zeisel. Understanding the role of nutrition in the brain and behavioral development of toddlers and preschool children: identifying and addressing methodological barriers. Nutritional Neuroscience An International Journal on Nutrition, Diet and Nervous System Vol. 12, Iss. 5, 2009 Volume 12, 2009

Indri Yunita S, Bunga Ch, Dini A. 2014. Determinan kemampuan motorik anak berusia 2-5 tahun, panel gizi makan. Juni 2014 Vol 37 (1) : 43-50

Katherine Alaimo, Christine M. Olson, Edward A. Food Insufficiency and American School-Aged Children's Cognitive, Academic, and Psychosocial Development. Frongillo, Jr. AAP News\& Journals Pediatrics. July 2001, Volume 108 / Issue 1

Lindawati. 2013. Faktor-faktor yang berhubungan dengan perkembangan anak toddler. Jurnal Health Quality Vol 4 No 1 November 2013.

Mariani Gabriela K. 2015. Hubungan status gizi dengan perkembangan motorik halus pada anak usia prasekolah di TK GMIM Solafide Kelurahan Uner Kecamatan Kawangkoan Induk. E journal keperawatan (e-kp) Vol 3 No 1 Februari 2015.
Mary Arimond ${ }^{3}$ and Marie T. Ruel. Dietary Diversity Is Associated with Child Nutritional Status: Evidence from 11 Demographic and Health Surveys. J. Nutr. October 1, 2004 vol. 134 no. 10 2579-2585

Rindu Dewi M, Faisal anwar. 2013. Kaitan antara Status Gizi, perkembangan motorik pada anak usia prasekolah, penelitian gizi dan makanan. Juni 2013 Vol 36 (1) 62-67.

Sally M. Grantham-Mc Gregor, Lia C.H. Fernald . Effects of integrated child development and nutrition interventions on child development nd nutritional status. Annals of the new York academy of sciences journal. Volume 1308, Pages 11-32. First published: 4 November 2013

Shannon E. Whaley, Marian Sigman, Charlotte Neumann, Nimrod Bwibo, Donald Guthrie, Robert E. Weiss, Susan Alber, and Suzanne P. Murphy. The Impact of Dietary Intervention on the Cognitive Development of Kenyan School Children. J. Nutr. November 1, 2003 vol. 133 no. 11 3965S-3971S

Sumithra Selvam, Tinku Thomas, Priya Shetty, K. Thennarasu, Vijaya Raman, Deepti Khanna. Development of norms for executive functions in typically-developing Indian urban preschool children and its association with nutritional status. Child Neuropsychology Journal. Pages 121 Received 24 Aug 2015, Accepted 25 Oct 2016, Published online: 01 Dec 2016

Tayong Siti Nurbaiti. 2016. Hubungan derajat stunting dengan perkembangan motorik halus anak usia 12-24 bulan. Jurnal Kesehatan Masyarakat Vol 1 No 4 April 2016. 